\title{
COMPUTER CONTROLLED MICROWAVE OVEN SYSTEM FOR RAPID WATER CONTENT DETERMINATION
}

\author{
by
}

Paul A. Gilbert

Geotechnical Laboratory

DEPARTMENT OF THE ARMY

Waterways Experiment Station, Corps of Engineers PO Box 631, Vicksburg, Mississippi 39181-0631

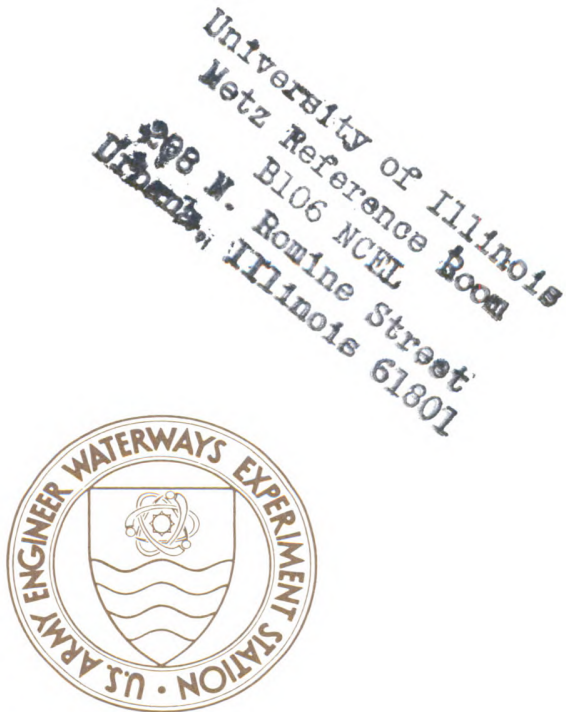

November 1988

Final Report

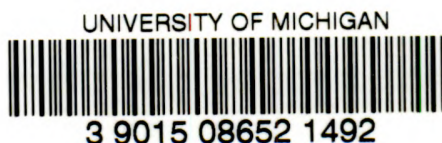

Prepared for US Army Engineer Division, Ohio River Cincinnati, Ohio 45201-1159 